\title{
ENSINAR O ESPÍRITO DA EMPRESA NA ESCOLA: A GUINADA POLÍTICA DOS ANOS 1980-2000 NA FRANÇA*
}

Selma VENCO ${ }^{1}$

\begin{abstract}
TANGUY, L. Enseigner l'esprit d'entreprise à lécole: le tournant politique des
\end{abstract} années 1980-2000 en France. Paris: La Dispute, 2016.

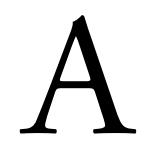

o longo de sua carreira como diretora de pesquisa no Centre National de la Recherche Scientifique (CNRS), Lucie Tanguy dedicou-se a analisar os te publicação, a socióloga francesa apresenta um profundo trabalho analítico sobre o curso das políticas de descentralizaçáo promovidas pela Comunidade Europeia nos últimos 30 anos e paulatinamente adotadas na França, as quais elegem a empresa como o lugar de formação. Em quatro estudos complementares a autora apresenta a adesão acrítica do Estado, da escola, das famílias e de parte dos profissionais da educação sobre a incorporação dos valores empresariais na formação de estudantes a partir dos 6 anos de idade.

A autora analisa os programas reconhecidos, legitimados e apoiados financeiramente pelo governo francês, cujo propósito é construir junto aos estudantes das escolas públicas o espírito empreendedor e desenvolver, segundo os termos afeitos a essa lógica, as competências para tal propósito. Um deles, promovido pela Federação EPA (Empreender para Aprender), composta por 15 associaçôes sem fins lucrativos, oferece três linhas de atuação, duas dirigidas ao público da educação básica: "Nossa cidade", destinada a crianças a partir de 6 anos, com o sentido de levá-las a conhecer os serviços oferecidos na cidade e nesse movimento compreender os mecanismos de circulação da moeda no capitalismo; e "Miniempresa", dedicada aos estudantes dos ensinos fundamental II e médio, conta com equipe formalmente "treinada" para dar suporte aos estudantes e professores na implementação do projeto, o que envolve a identificação de parceiros na cidade (empresários, padrinhos da miniempresa), a venda de açóes da empresa para pais e professores para compra de materiais, a seleção dos estudantes que ocuparão cargos (presidente, diretor de recursos humanos, de marketing), a organização de visitas, a produção, a formulação de orçamento e as demais etapas constituintes

\footnotetext{
*Livro não publicado no Brasil.

${ }^{1}$ Universidade Estadual de Campinas, Faculdade de Educação - Campinas (SP), Brasil.

E-mail: selma.venco@gmail.com

DOI: $10.1590 / \mathrm{ES} 0101-73302017178410$
} 
do funcionamento de uma corporação. A intencionalidade é nítida no programa: a construção dos valores caros ao capitalismo e a exclusão de questóes envolvendo as condições de trabalho, os direitos do trabalhador, a representação sindical e outras formas de coletivos no ambiente de trabalho. A pesquisa constatou que a percepção dos docentes divide-se entre o encantamento e a crítica: parte fascinada pelo entusiasmo dos estudantes em relação ao projeto; e, outra parte consciente sobre o papel de formar cidadãos, e não agentes econômicos.

Outra pesquisa apresentada no livro destaca a ruptura com o modelo propagado no pós-II Guerra Mundial, que valorizava a escola como local privilegiado para formar cidadáos. No contexto da economia mundializada, de concorrência exacerbada e com altas taxas de desemprego juvenil, a França opta pela formação profissional destinada aos jovens de 16 a 25 anos, inspirada no modelo alemão de alternância entre empresa e escola. $\mathrm{O}$ programa implica no pagamento ao aprendiz de percentuais variáveis do salário mínimo; esses jovens são supervisionados, na empresa, por um "mestre de aprendizagem". Todavia, a política reproduz formas de segregação semelhantes às praticadas no mercado de trabalho, posto que as estatísticas indicam que os participantes do programa são majoritariamente homens, brancos e oriundos de classes populares.

\section{Região: a nova instância de poder}

A tradição francesa de forte centralização da política vem sendo gradativamente rompida.

O movimento de transferência de competência do Estado às regióes foi realizado progressivamente em cinco décadas, em nome da maior eficiência na oferta dos serviços à população e visando conferir respostas às críticas sobre a excessiva centralização da política. Os marcos legais, construídos em três fases, quais sejam: I, de 1992 a 1999, contemplaram os textos fundadores; a etapa II, em 2003, dedicou-se a regular a descentralização da República, tendo sido concluída em 2004 com a lei referente às liberdades e às responsabilidades locais; e, por fim, em 2014, a denominada modernização da ação pública territorial, conferindo poderes às coletividades.

Lucie Tanguy exemplifica a descentralização associada ao espírito da empresa na escola analisando os centros de formação profissional e destaca o abandono dos princípios políticos pautados na igualdade de oportunidades, conclamados até início dos anos 1990, substituídos por palavras de ordem, como objetivos, eficácia, mensuraçóes de acesso e outros termos caros ao gerencialismo.

Se, por um lado, o Estado conservou algumas de suas funçóes, por outro, permitiu a ampla participação de atores locais nas decisóes referentes à formação dos jovens. No modelo anterior, a formação profissional era debatida entre o Ministério da Educação e representantes dos empregadores e trabalhadores. Naquela perspec- 
tiva, privilegiavam-se a cultura técnica, o estudo aprofundado dos materiais, os processos de trabalho e as normas de segurança e direitos do trabalho. Na nova configuração, as regióes definem a formação, segundo as demandas das empresas; instala-se a noção de percurso profissional essencialmente associada à ideia de formação ao longo de toda a vida, e não mais àquela de carreira, dado o novo cenário marcado pela incerteza profissional. Não obstante, o Estado tem destinado vultuosos recursos aos centros regionais de formação profissional, os quais, contraditoriamente, não raro, deixam de oferecer certificação capaz de conferir acesso ao posto de trabalho.

\section{Campus profissional: o DNA do território}

A descentralização trouxe maior poder às regióes; no que tange à formação profissional, construiu-se uma política semelhante à dos Institutos Federais no Brasil, com toques de requintes permitidos a um país situado no centro da economia mundial. Foram criados centros de excelência regionais dedicados a um setor da economia, os quais oferecem formação básica até o ensino superior, contam com laboratórios de pesquisa equipados com tecnologia de ponta e destinam-se ao público jovem e ao trabalhador que busca formação continuada. A organização do campus é feita por meio de um processo de colaboração entre os atores locais, mobilizados em criar um "DNA regional", um currículo do território e os ditos "empregos do futuro".

Destaca-se que os centros contam com importante aporte financeiro do Ministério da Educação, concretizando o avanço do estabelecimento das parcerias público-privadas em um país, até então, zeloso pela soberania do Estado. Essas podem ser observadas desde a compra e o uso de equipamentos até a decisão do estatuto do campus, que pode ser público, associativo ou, ainda, agrupamento de interesse público (GIP).

$\mathrm{Na}$ esteira das inovaçóes, a autora problematiza o sentido das medidas de descentralização. Supõe que, por princípio, tal movimento significaria um avanço nos processos de democratização e participação dos atores locais.

Mas, é forçoso indagar: quem, de fato, são os protagonistas e quais são as suas respectivas intencionalidades?

À luz de um liceu profissionalizante com alternâncias teórica e prática na empresa, Lucie Tanguy analisa o peso das decisóes. A empresa que abriga os estudantes em regime de alternância alterou, autonomamente, a carga e a distribuição horária do curso em detrimento do definido pela educaçáo nacional, defendendo maior tempo de prática e menor carga teórica, contrariando as diretrizes legais. Diante de resistências dos profissionais da educação, a empresa reúne as famílias oferecendo contratos de aprendizagem no valor de 800 euros mensais aos jovens estudantes, em um contexto local de alta taxa de desemprego juvenil, culminando em autorização legal de funcionamento. 
A indagação presente na obra refere-se à ausência de debate coletivo sobre as normas e os limites de participação e atuação, especialmente sobre a elevaçáo do lugar das empresas como formadoras de comportamentos e aquisiçáo de valores, além de sua atuação no interior das escolas e junto às famílias.

Tais desdobramentos, conclui a autora, resultam da concepção política predominante na Comunidade Europeia. Desde o Tratado de Maastricht (1992), ressalta-se a obsolescência das instituiçôes educacionais e reconhece-se a empresa como a instituição mais afeita à formação de jovens. Uma das evidências é o livro branco Ensinar e Aprender (1997), documento publicado pela Comunidade Europeia, que se sustenta na teoria do capital humano, preconiza a responsabilização individual na construção das competências e um casamento duradouro entre os mundos da escola e da empresa.

Há nas políticas da Comissão Europeia, nos documentos e discursos pela autora analisados, a clara defesa do ensino do empreendedorismo em larga escala e a responsabilização dos professores, pois "esses são incapazes de ensinar o espírito empreendedor, visto que são funcionários públicos que optaram pela segurança, e não por entrar em um mundo de risco..." (Androulla Vassiliou, membro da subcomissão educação, cultura, Comissão Europeia, 2012 apud TANGUY, 2016, p. 184).

Aos professores, mais uma vez, lhes é imputado o fracasso da escola, nesse contexto, em razão da ausência de respostas ao mundo capitalista e à "sociedade cognitivista". Os programas analisados pela autora apresentam majoritariamente a aprendizagem de comportamentos, e não de conhecimento, pois o empreendedorismo se define como um "saber-ser" adquirido via treinamento, com técnicas de "coach", reafirmando, assim, uma face obsoleta da escola.

São muitas as questóes suscitadas pela leitura do livro de Lucie Tanguy, que, segundo sua própria tradição analítica, finaliza-o sem a pretensão de trazer respostas, mas convoca a sociedade, sobretudo pais e sindicatos vinculados à educação, a refletir sobre os caminhos que estão sendo traçados para a educação, que afiançam a empresa como lugar de formaçáo de crianças e jovens, a fim de fazer valer os interesses do capitalismo.

Recebido em 11 de abril de 2017. Aprovado em 12 de abril de 2017. 